\title{
100 years of the Revista de Medicina, of the University of São Paulo School of Medicine - Message from the Governor of the State of São Paulo
}

century ago, the Revista de Medicina of the University of São Paulo School of Medicine was
born. It was a sign of São Paulo's boldness and the commitment of its academic and social leaders to the progress of the medical sciences.

In July 1916, USP students launched the most long-lasting journal of scientific diffusion produced by medical students in Brazil, a bulletin that was already committed to the advances in science and its social applications.

Since then, students, medical professors, national and foreign researchers, began to receive safe and first-hand information on what is new and relevant in the world of health.

Over almost the entire Twentieth century, and the beginning of this Twenty-First century, the journal published countless articles, essays, testimonials, interviews, and news in general, deserving its acknowledgment worldwide.

Nowadays, the Revista de Medicina remains a valuable source of information and services provided to the medical community. In this significant occasion, I congratulate its team of medical writers, researchers, employees, and the board of USP's School of Medicine.

As the State governor and a physician by profession, an admirer of the quality of the Paulist research, and aware of the importance of scientific knowledge for the development of the country, I am particularly pleased to be a part of this festive event.

São Paulo currently accounts for more than half of all research performed in Brazil, for the largest technical and technological education network in the country, and for the three most prestigious Brazilian public universities. It is also the only Brazilian state to allocate $1 \%$ of its annual tax revenue to research. These resources, which in the current year, 2016, reached the impressive amount of 1.1 billion Reais, are invested in scientific and technological development

I hereby salute all those who have been contributing to keep alive the excellence of the Revista de Medicina, and I wish that it remains the most faithful interpreter of the achievements and efforts of the School of Medicine, one of the most prestigious medical schools in the world.

Geraldo Alckmin

Governor of the State of São Paulo 


\title{
Mensagem de GA | 100 anos da Revista de Medicina da USP
}

igno do arrojo de São Paulo e do compromisso de suas lideranças acadêmicas e Revista de Medicina da FMUSP.

Mais longevo órgão de divulgação produzido por graduandos de Medicina do Brasil, em julho de 1916 alunos da USP lançavam a publicação, já compromissada com os avanços da ciência e suas aplicações sociais.

Desde então, estudantes, professores de medicina e pesquisadores nacionais e estrangeiros passaram a ter o privilégio de receber informações seguras e em primeira mão sobre as novidades do mundo da saúde.

Ao longo de praticamente todo o século XX e neste início de século XXI, a revista publicou um número incontável de artigos, ensaios, depoimentos, entrevistas e notícias em geral, merecendo por isso, e com justiça, seu reconhecimento urbi et orbi.

Hoje, a Revista de Medicina segue sendo uma fonte preciosa de informação e de serviços prestados à comunidade médica. Nesta ocasião tão festiva como significativa, congratulo-me com sua equipe de redatores médicos, pesquisadores, funcionários e a direção da Faculdade de Medicina da USP. Como governador do estado e como médico, conhecedor e admirador da qualidade das pesquisas paulistas e ciente da importância do conhecimento científico para o desenvolvimento do País, sinto particular satisfação em poder compartilhar esta data festiva.

Hoje, São Paulo responde por mais da metade de todas as pesquisas feitas no Brasil, pela maior rede de ensino técnico e tecnológico no país e pelas três mais conceituadas universidades públicas brasileiras. É também a única unidade da federação a destinar 1\% de sua receita tributária anual para a pesquisa; estes recursos, que neste ano de 2016 alcançaram o impressionante valor de 1,1 bilhão de reais, são aplicados em desenvolvimento científico e tecnológico.

Cumprimento aqui todos aqueles que têm contribuído para manter viva a excelência da Revista de Medicina e desejo que ela continue a mais fiel tradutora das conquistas e esforços da Faculdade de Medicina da USP, uma das mais renomadas escolas médicas do mundo.

\author{
Geraldo Alckmin
}

Governador do Estado de São Paulo 